\title{
Determinants of Performance and Structural Relationships of Rice Processing Industry Performance: Resources Based View Approach
}

\author{
DOI: 10.12776/QIP.V25I3.1587
}

\author{
T.S. Bahri, Dedi B. Hakim, Bambang Juanda, Sahara Sahara
}

Received: 2021-06-14 Accepted: 2021-09-19 Published: 2021-11-30

\begin{abstract}
Purpose: Attention to the capacity of rice milling companies is very important because this company is the main business actor that creates added value. This study aims: (1) to identify the determinants of the performance of the rice milling industry based on the Resources Based View (RBV) framework and (2) to formulate the structural relationship that occurs between the resources of rice milling companies on business performance.
\end{abstract}

Methodology/Approach: RBV framework and formulate the structural relationships that occur between company resources and business performance Through the SEM-PLS method.

Findings: Structurally, the results of the analysis show that the performance of rice mills is directly determined by reputation with the largest path coefficient of 0.856 and is then followed by marketing differentiation 0.184 and human capital 0.1822 , while tangible assets directly have a negative relationship (-0.236) but indirectly through the latent variable the reputation as a mediator has a greater (0.558) and significant positive relationship.

Research Limitation/Implication: The research has empirical implications that not all RBV dimensions can predict the performance of the rice industry, especially organizational variables. This illustrates that in reality in the manufacturing industry, organizational function variables do not really affect the produced.

Originality/Value of paper: This article becomes an important for policymakers in Aceh Province to develop the rice milling industry based on the RBV.

Category: Research paper

Keywords: performance; rice milling; RBV; SEM-PLS 


\section{INTRODUCTION}

The potential of Aceh Province as a large grain producer has not been accompanied by its ability to produce large amounts of rice as well. This is related to the status of competitiveness of the Rice Industry in Aceh, where this is greatly influenced by the capacity of business actors involved in the rice/rice production value chain.

The development of rice milling production capacity is still facing obstacles. This can be caused mainly by internal factors from the entrepreneur/company. Nonetheless, as well as external factors such as infrastructure and government regulations are likely to have an influence as well.

Attention to the capacity of Rice Milling Companies is very important because this company is the main business actor that creates added value. However, there is currently no knowledge regarding the relationship between the capacity of rice millers and business performance (such as productivity, profitability, and efficiency). Related to this, the RBV perspective - as pioneered by Barney (1991), Peteraf (1993), Penrose (1959), Teece, Pisano and Shuen (1997) can answer the problem of business structure, conduct and performance. With this resource-based view perspective, it is formulated in a structural relationship that the source of competitive advantage comes from internal companies where every company has different resources and different business strategies so that the resulting performance is different.

The RBV framework according to Penrose (1959) states that company performance is a combined effect of the administrative and entrepreneurial attributes of its managers. The administrative attribute is seen from the decision making and resource allocation behaviour, while the entrepreneurial attribute refers to the formation of a portfolio of opportunities and finding ways to exploit them. This is the basis of this research model, where the main aspects studied are the main variables determining company performance and how to exploit them for the benefit of achieving the best possible company performance.

The RBV literature generally considers the performance of a firm influenced by the combination of own resources and capabilities (Kaleka, 2002). Resources are broadly divided according to Rothaermel (2015), into two categories: namely Tangible (labour, capital, land, building, plant, equipment) and Intangible (culture, knowledge, brand quality, reputation, intellectual property).

The RBV framework argues that company resources, including all assets, capabilities, organizational processes, company attributes, information, knowledge, etc., produce a sustainable competitive advantage. These resources are controlled by the company, which enables the company to understand and implement strategies that increase its efficiency and effectiveness.

According to Madhani (2010), RBV is useful in identifying the basis on which the company's resources and capabilities serve as a source of sustainable competitive advantage. Thus, resources and capabilities are the fundamental 
basis of every source of profit. Valuable resources are called strategic assets. RBV asserts that ownership and control of strategic assets determine, which organizations will gain more profits and enjoy a competitive advantage over others.

Resources can be considered as inputs that enable a company to carry out its activities. Internal resources and capabilities determine the strategic choices companies make when competing in their external business environment. These company's capabilities (such as the rice milling industry in Pidie District, Aceh Besar, and North Aceh) also allow some companies (rural small rice milling industry) to add value to the customer value chain, develop new products, or develop new markets. RBV leverages the existing resources and capabilities within the organization to develop a sustainable competitive advantage. According to the RBV approach, not all company resources are strategic and therefore a source of competitive advantage. Competitive advantage only occurs when there are situations of resource heterogeneity and resource immobility.

In the context of the performance of the rice processing industry, the proportion of added value to rice and processing is one of the drivers of the regional economy. The empirical study of the rice value chain is widely used in terms of business management, financial and industrial value chains such as Ritthaisong, Johri and Speece (2014), Nkuba et al. (2016), Suoth (2017) and Pavithra et al. (2018). RBV approach needs to be considered in the rice business value chain between regions. Bahri et al. (2020) found that the importance of understanding rice industry companies to create added value. Comprehensive information on value chain structure and performance will provide direction for local investment options/opportunities.

This study aims (1) to identify the determinants of the performance of the rice milling industry based on the Resources Based View (RBV) framework and (2) to formulate the structural relationship that occurs between the resources of rice milling companies on business performance.

\section{METHODOLOGY}

The research was conducted from March to May 2020, with the research locations in Aceh Province represented by Aceh Besar District, Pidie Regency, and North Aceh Regency. The first stage of research sampling for farmer respondents used a non-probabilistic method with purposive sampling. Sampling of farmer respondents using a non-probalistic sampling method that is deliberately based on consideration of several characteristics that are in accordance with the characteristics needed to answer the research objectives (Juanda, 2009). The criteria for the sample of farmers consist of: having competence and work experience of at least 1 (one) year in the value chain, knowing the structure of production costs, and rice trading volume. 
Furthermore, the overseas rice milling industry companies used the snowballing method. This method, the sample is obtained from the respondent's information which was first obtained and continued until the data is obtained according to the research design (Naderifar, Goli and Ghaljaie, 2017).

The survey was conducted using non-probability sampling, namely by purposive sampling, the number of respondents managing 36 refineries/rice mills. In analysing structural relationships Hair, Ringle and Sarstedt (2013) offer the SEM-PLS method. The data were processed using Smart PLS 2 software for SEM-PLS.

\subsection{Description of Industry Performance Determinants}

Referring to Ritthaisong, Johri and Speece (2014) and Rothaermel and Deeds (2001), there are nine latent variables used to generate the RBV analysis framework. Each latent variable has 36 indicators of variable construction which are tabulated into nominal and interval/Likert scales. Specifically, the construction of each latent variable and the construction of the measured variables are described in the following description table.

Table 1 - Variable Description

\begin{tabular}{|c|c|}
\hline Variable Latent & Measurable variables \\
\hline \multirow[t]{6}{*}{ X1 (Human Capital) } & X11 Working Days/Year (Day) \\
\hline & X12 Length of employment of employees (Year) \\
\hline & X13 Number of Employees (Person) \\
\hline & X14 Number of experienced employees (Person) \\
\hline & X15 High school employees (Person) \\
\hline & X16 There are professional HR (Likert Scale 1-4) \\
\hline \multirow[t]{6}{*}{ X2 (Tangible Asset) } & X21 Milling Machine Capacity (Ton/Hour) \\
\hline & X22 Polish Machine Capacity (Ton/Hour) \\
\hline & X23 Packing Capacity (Ton/Hour) \\
\hline & X24 Dryer Capacity (Ton/Hour) \\
\hline & X25 Vehicle Capacity (Ton) \\
\hline & X26 Warehouse Capacity (Ton) \\
\hline \multirow[t]{4}{*}{ X3 (Reputation) } & X31 Working Capital (IDR / Rupiah) \\
\hline & X32 Cost of Buying Grain (IDR / Rupiah) \\
\hline & X33 Bank Relationship (Likert Scale 1-4) \\
\hline & X34 Old Business (Year) \\
\hline
\end{tabular}




\begin{tabular}{|c|c|}
\hline Variable Latent & Measurable variables \\
\hline \multirow[t]{2}{*}{ X4 (Low Cost Strategy) } & X41 Waste for Fuel (Likert Scale 1-4) \\
\hline & X42 Pressing the price of raw materials (Likert Scale 1-4) \\
\hline \multirow[t]{4}{*}{ X5 (Market Differentiation) } & X51 Quality of packaging (Likert Scale 1-4) \\
\hline & X52 Packing volume variation (Likert Scale 1-4) \\
\hline & X53 Large quantity contract special price (Likert Scale 1-4) \\
\hline & X54 Sells cheaper than competitors (Likert Scale 1-4) \\
\hline \multirow[t]{10}{*}{ X6 (Organization) } & X61 There are Company Procedures (Likert Scale 1-4) \\
\hline & X62 There is a contract (Likert Scale 1-4) \\
\hline & X63 There is an employee data system (Likert Scale 1-4) \\
\hline & X64 There is a company establishment document (Likert Scale 1-4) \\
\hline & X65 There are clear performance indicator (Likert Scale 1-4) \\
\hline & X66 There is a personnel SOP (Likert Scale 1-4) \\
\hline & X67 There is a recruitment standard (Likert Scale 1-4) \\
\hline & X68 There is a career path (Likert Scale 1-4) \\
\hline & X69 There is a staff regeneration (Likert Scale 1-4) \\
\hline & X610 Special Marketing Unit (Likert Scale 1-4) \\
\hline \multirow[t]{2}{*}{ X7 (Side Product) } & X71 Production-Bran (Ton) \\
\hline & X72 Production-Groats (Ton) \\
\hline \multirow[t]{2}{*}{ X8 (Performance) } & X81 Advantage (R/C) (Ratio) \\
\hline & X82 Profit/Working Capital (Ratio) \\
\hline
\end{tabular}

Notes: A Likert scale assumes that the strength/intensity of an attitude is linear, i.e. on a continuum from strongly agree (4) to strongly disagree (1), and makes the assumption that attitudes can be measured.

\subsection{Model Hypothesis SEM-PLS}

The RBV focuses on internal resources and capabilities to identify the determinants of a firm's competitive advantage and performance (RamonJeronimo, Florez-Lopez and Araujo-Pinzon, 2019). The hypothesis of this research is based on Spanos and Spyros (2001) that the contribution of company assets in creating profits is indirectly carried out in the form of corporate strategy and then creates what is called the "utility effect". Value creation for buyers, either in the form of product differentiation or produced at a lower cost (low-cost production).

Furthermore, based on Galbreath (2005) dividing company resources as follows: (1) Tangible resources which include (a) financial assets and (b) physical assets; (2) Intangible resources include (a) intellectual property assets, (b) organizational assets, and (c) reputation assets, (3) intangible resources which are skills that 
include management capabilities (soft skills) and abilities. technical (hard skills). For these two opinions, the three major parts of the model, namely company assets, strategy, and performance are made in the structural relationship model as shown in Figure 1.

Resources or company assets consist of Human Capital (HC), Tangible Assets (TA), Reputation, and Organizational. The company's strategies are the LowCost strategy (LC) and Market Differentiation strategy (MD). Both of these have an influence on the performance variable. In addition, there are additional variables in the form of side products or side products, which also have an influence on the performance of rice mills.

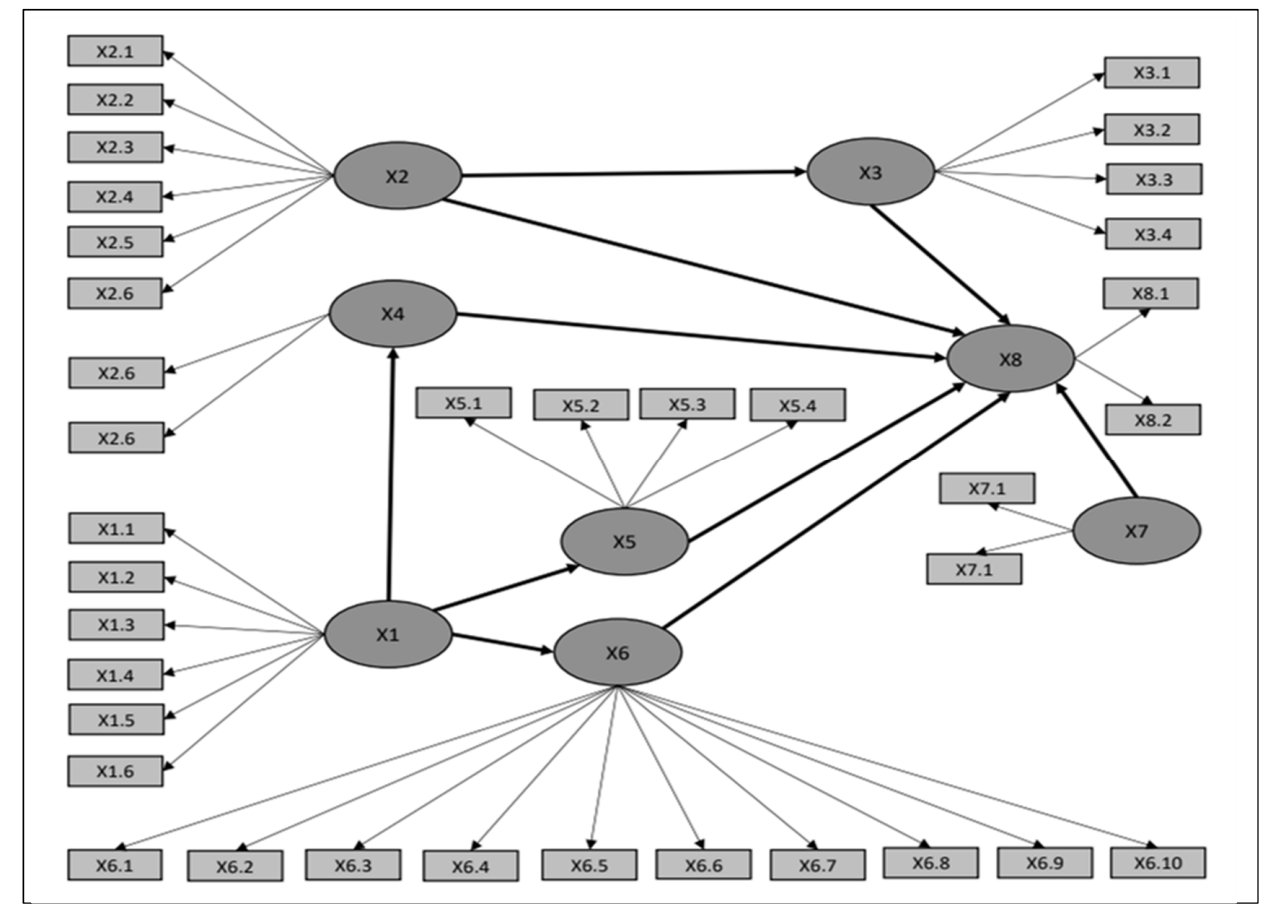

Figure 1 - SEM-PLS Model Relationship Between Assets, Strategy, and Performance of Rice Mills

\section{RESULTS AND DISCUSSION}

\subsection{Formatting Mathematical Equations}

Based on data processing from 36 Rice Refineries, the best model is produced as in Table 2, where there are 8 latent or construct variables and 25 measurable variables. This result is a model that is reduced from the original model that included 36 measured variables. The measured variable of the reduction model is a variable that has a loading factor of more than 0.7 . 
Judging from the AVE criteria, Composite Reliability, R Square, and Cronbach alpha, the model has good quality, so it can be used as a prediction tool. The latent variable X1 (Human Capital) is reflected in the measured variables X11 (Days of Work/Th), X13 (Number of employees), X14 (Experienced employees), and X15 (Number of high school employees).

$\mathrm{X} 2$ (Tangible Asset) is reflected in the measured variables X21 (Milling machine capacity), X22 (Polish machine capacity), X23 (Packing Capacity), X24 (Dryer capacity), X25 (Vehicle capacity), X26 (Warehouse capacity). X3 Reputation is reflected by the measured variables X31 (Working capital), X32 (Cost of Buying Grain), X33 (Bank).

$\mathrm{X} 4$ (Low-Cost Strategy) is reflected in the measured variable X41 (Waste for Fuel), X42 (Pressing the price of raw materials). X5 (Market Differentiation) X51 (Packaging quality), X52 (Variation pack volume). X6 (Organization) is reflected by the measured variables X61 (There is Company Procedure), X62 (There is a contract), X63 (There is an employee data system), X64 (There is a Company Establishment Document).

X7 (Side Product), reflected by the measured variable X71 (Bran-Production), $\mathrm{X} 72$ (Groat-Production). X8 (Performance) is reflected by the measured variables X81 (R/C profit), X82 (Profit/working capital). Based on data processing based on hypotheses, eight latent variables or constructs and 25 measurable variables were selected, where these variables were identified as factors that determine the performance of rice refineries.

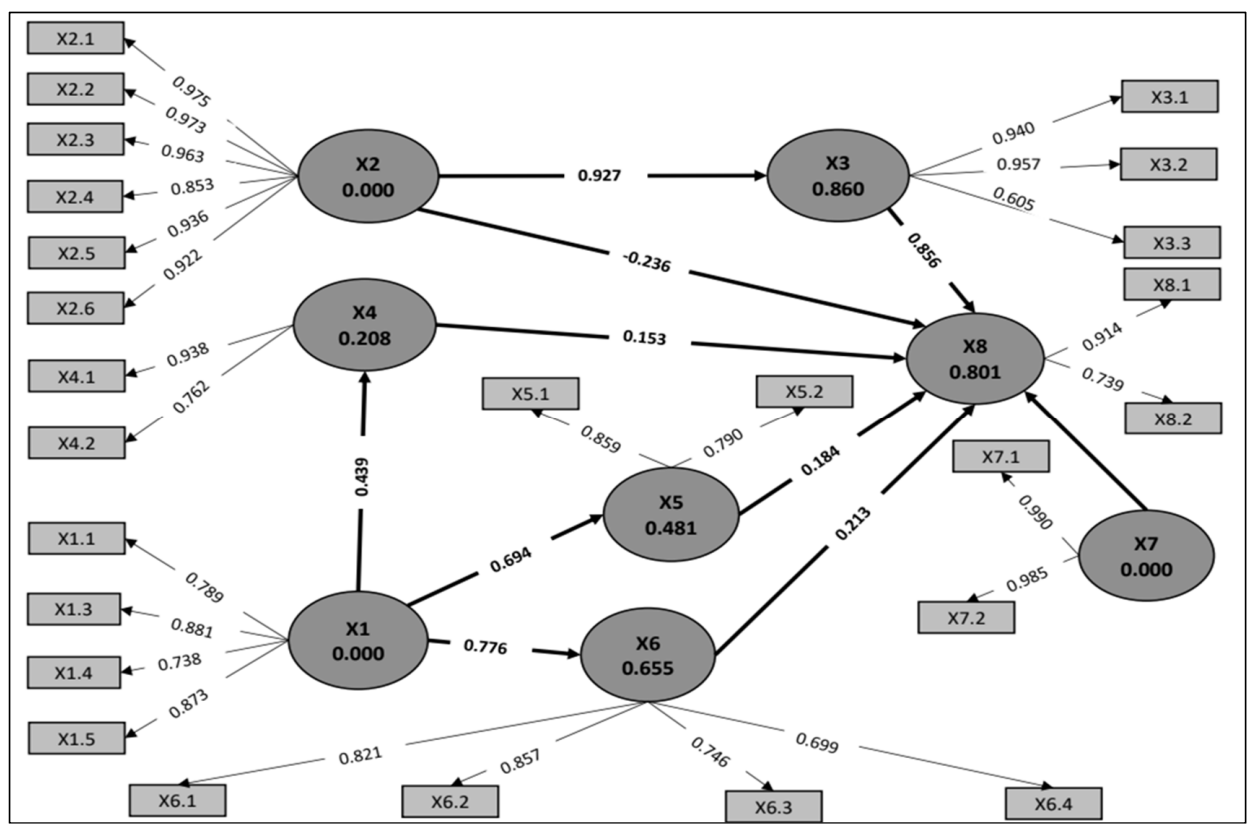

Figure 2 - Results of Data Processing With SEM-PLS: Relationship of Assets, Strategy, and Performance of Rice Mills 
Table 2 - Overview Quality Criteria Variables SEM Models PLS

\begin{tabular}{|c|c|c|c|c|c|c|c|}
\hline \multicolumn{6}{|c|}{ Overview Inner Model } & \multicolumn{2}{|c|}{ Overview Outer Model } \\
\hline AVE & $\begin{array}{l}\text { Composite } \\
\text { Reliability }\end{array}$ & $\begin{array}{c}\mathbf{R} \\
\text { Square }\end{array}$ & $\begin{array}{l}\text { Cronbach' } \\
\text { s Alpha }\end{array}$ & Communality & Redundancy & $\begin{array}{c}\text { Measured } \\
\text { Variable }\end{array}$ & $\begin{array}{l}\text { Loading } \\
\text { Factor }\end{array}$ \\
\hline \multicolumn{8}{|c|}{ Variable Laten: X1 Human Capital } \\
\hline \multirow[t]{4}{*}{0.677} & \multirow[t]{4}{*}{0.893} & \multirow[t]{4}{*}{0} & \multirow[t]{4}{*}{0.839} & \multirow[t]{4}{*}{0.676} & \multirow[t]{4}{*}{0} & $\begin{array}{l}\text { X11 } \\
\text { Working } \\
\text { Days/Year }\end{array}$ & 0.789 \\
\hline & & & & & & $\begin{array}{l}\text { X13 } \\
\text { Number of } \\
\text { Employees }\end{array}$ & 0.881 \\
\hline & & & & & & $\begin{array}{l}\text { X14 } \\
\text { Employee } \\
\text { Experience }\end{array}$ & 0.738 \\
\hline & & & & & & $\begin{array}{l}\text { X15 } \\
\text { High school } \\
\text { employees }\end{array}$ & 0.873 \\
\hline \multicolumn{8}{|c|}{ Variable Laten: X2 Tangible Asset } \\
\hline \multirow[t]{6}{*}{0.880} & \multirow[t]{6}{*}{0.978} & \multirow[t]{6}{*}{0} & \multirow[t]{6}{*}{0.972} & \multirow[t]{6}{*}{0.880} & \multirow[t]{6}{*}{0} & $\begin{array}{l}\text { X21 } \\
\text { Milling Machine } \\
\text { Capacity }\end{array}$ & 0.975 \\
\hline & & & & & & $\begin{array}{l}\text { X22 } \\
\text { Polish Machine } \\
\text { Capacity }\end{array}$ & 0.973 \\
\hline & & & & & & $\begin{array}{l}\text { X23 } \\
\text { Packing Capacity }\end{array}$ & 0.963 \\
\hline & & & & & & $\begin{array}{l}\text { X24 } \\
\text { Capsitas Dryer }\end{array}$ & 0.853 \\
\hline & & & & & & $\begin{array}{l}\text { X25 } \\
\text { Vehicle Capacity }\end{array}$ & 0.936 \\
\hline & & & & & & $\begin{array}{l}\text { X26 } \\
\text { Warehouse } \\
\text { Capacity }\end{array}$ & 0.922 \\
\hline \multicolumn{8}{|c|}{ Variable Laten: X3 Reputation } \\
\hline \multirow[t]{3}{*}{0.722} & \multirow[t]{3}{*}{0.882} & \multirow[t]{3}{*}{0.860} & \multirow[t]{3}{*}{0.802} & \multirow[t]{3}{*}{0.722} & \multirow[t]{3}{*}{0.617} & $\begin{array}{l}\text { X31 } \\
\text { Working Capital }\end{array}$ & 0.940 \\
\hline & & & & & & $\begin{array}{l}\text { X32 } \\
\text { B-buy grain }\end{array}$ & 0.957 \\
\hline & & & & & & $\begin{array}{l}\text { X33 } \\
\text { Bank }\end{array}$ & 0.605 \\
\hline \multicolumn{8}{|c|}{ Variable Laten: X4 Low Cost Strategy } \\
\hline \multirow[t]{2}{*}{0.731} & \multirow[t]{2}{*}{0.843} & \multirow[t]{2}{*}{0.208} & \multirow[t]{2}{*}{0.659} & \multirow[t]{2}{*}{0.731} & \multirow[t]{2}{*}{0.140} & $\begin{array}{l}\text { X41 } \\
\text { Waste for Fuel }\end{array}$ & 0.938 \\
\hline & & & & & & $\begin{array}{l}\text { X42 Pressing the } \\
\text { price of raw mat. }\end{array}$ & 0.762 \\
\hline
\end{tabular}




\begin{tabular}{|c|c|c|c|c|c|c|c|}
\hline \multicolumn{6}{|c|}{ Overview Inner Model } & \multicolumn{2}{|c|}{ Overview Outer Model } \\
\hline AVE & $\begin{array}{l}\text { Composite } \\
\text { Reliability }\end{array}$ & $\begin{array}{c}\mathbf{R} \\
\text { Square }\end{array}$ & $\begin{array}{l}\text { Cronbach' } \\
\text { s Alpha }\end{array}$ & Communality & Redundancy & $\begin{array}{c}\text { Measured } \\
\text { Variable }\end{array}$ & $\begin{array}{l}\text { Loading } \\
\text { Factor }\end{array}$ \\
\hline \multicolumn{8}{|c|}{ Variable Laten: X5 Market Differentation } \\
\hline \multirow[t]{2}{*}{0.682} & \multirow[t]{2}{*}{0.810} & \multirow[t]{2}{*}{0.481} & \multirow[t]{2}{*}{0.536} & \multirow[t]{2}{*}{0.682} & \multirow[t]{2}{*}{0.325} & $\begin{array}{l}\text { X51 } \\
\text { Quality of } \\
\text { packaging }\end{array}$ & 0.859 \\
\hline & & & & & & $\begin{array}{l}\text { X52 } \\
\text { Packing volume } \\
\text { variation }\end{array}$ & 0.790 \\
\hline \multicolumn{8}{|c|}{ Variable Laten: X6 Organization } \\
\hline \multirow[t]{4}{*}{0.613} & \multirow[t]{4}{*}{0.863} & \multirow[t]{4}{*}{0.655} & \multirow[t]{4}{*}{0.788} & \multirow[t]{4}{*}{0.613} & \multirow[t]{4}{*}{0.396} & $\begin{array}{l}\text { X61 } \\
\text { Existing } \\
\text { Company } \\
\text { Procedures }\end{array}$ & 0.821 \\
\hline & & & & & & $\begin{array}{l}\mathrm{X} 62 \\
\text { There is a } \\
\text { contract }\end{array}$ & 0.857 \\
\hline & & & & & & $\begin{array}{l}\text { X63 } \\
\text { There is an } \\
\text { employee data } \\
\text { system }\end{array}$ & 0.746 \\
\hline & & & & & & $\begin{array}{l}\text { X64 } \\
\text { There is } \\
\text { Perus_Doc }\end{array}$ & 0.699 \\
\hline \multicolumn{8}{|c|}{ Variable Laten: X7 Side Product } \\
\hline \multirow[t]{2}{*}{0.975} & \multirow[t]{2}{*}{0.987} & \multirow[t]{2}{*}{0} & \multirow[t]{2}{*}{0.974} & \multirow[t]{2}{*}{0.975} & \multirow[t]{2}{*}{0} & $\begin{array}{l}\text { X71 } \\
\text { Production-Bran }\end{array}$ & 0.990 \\
\hline & & & & & & $\begin{array}{l}\text { X72 } \\
\text { Production-MEN }\end{array}$ & 0.985 \\
\hline \multicolumn{8}{|c|}{ Variable Laten: X8 Performance } \\
\hline \multirow[t]{2}{*}{0.690} & \multirow[t]{2}{*}{0.815} & \multirow[t]{2}{*}{0.801} & \multirow[t]{2}{*}{0.573} & \multirow[t]{2}{*}{0.690} & \multirow[t]{2}{*}{0,153} & $\begin{array}{l}\text { X81 } \\
\text { Advantage (R/C) }\end{array}$ & 0.914 \\
\hline & & & & & & $\begin{array}{l}\text { X82 } \\
\text { (Profit/working } \\
\text { capital) }\end{array}$ & 0.739 \\
\hline
\end{tabular}

The model obtained produces a path coefficient for each of the hypothesized relationships. In Table 3, it can be seen that of the 11 relationship paths, 9 pathways have significant coefficients. The largest coefficient is X2 TA $\rightarrow \mathrm{X} 3$ REPUTATION (0.927), followed by X3 REPUTATION $\rightarrow$ X8 PERFORMANCE (0.856).

The X1 (Human Capital) construct has a significant direct relationship to the X8 (performance) construct and has a significant total effect value (0.2068) which is the total direct and indirect path coefficient on performance. 
Table 2 - Path Analysis Results

\begin{tabular}{|c|c|c|c|c|}
\hline \multirow[t]{2}{*}{ Path description } & \multicolumn{2}{|c|}{ Direct Path } & \multicolumn{2}{|c|}{ Total Effect } \\
\hline & Coefficient & $\begin{array}{c}\text { T Statistics } \\
\text { (|O/STERR|) }\end{array}$ & Coefficient & $\begin{array}{l}\text { T Statistics } \\
(\mid \text { O/STERR } \mid)\end{array}$ \\
\hline $\mathrm{X} 1 \mathrm{HC} \rightarrow \mathrm{X} 4 \mathrm{LC}$ & 0.457 & $9.615 * *$ & 0.457 & $9.615 * *$ \\
\hline $\mathrm{X} 1 \mathrm{HC} \rightarrow \mathrm{X} 5 \mathrm{MD}$ & 0.694 & $18.728 * *$ & 0.694 & $18.728 * *$ \\
\hline $\mathrm{X} 1 \mathrm{HC} \rightarrow \mathrm{X} 6 \mathrm{ORG}$ & 0.809 & $43.556 * *$ & 0.809 & $43.556 * *$ \\
\hline $\mathrm{X} 1 \mathrm{HC} \rightarrow \mathrm{X} 8$ Performance & 0.182 & $2.273 * *$ & 0.207 & $2.409 * *$ \\
\hline $\mathrm{X} 2 \mathrm{TA} \rightarrow \mathrm{X} 3$ REPUTASI & 0.927 & $67.833 * *$ & 0.927 & $67.833 * *$ \\
\hline $\mathrm{X} 2 \mathrm{TA} \rightarrow \mathrm{X} 8$ Performance & -0.237 & $1.435 \mathrm{Ns}$ & 0.558 & $4.235 * *$ \\
\hline X3 Reputation $\rightarrow$ X8 Performance & 0.856 & $3.970 * *$ & 0.855 & $3.970 * *$ \\
\hline X4 LC $\rightarrow$ X8 Performance & 0.153 & $3.589 * *$ & 0.153 & $3.589 * *$ \\
\hline X5 MD $\rightarrow$ X8 Performance & 0.184 & $3.770 * *$ & 0.184 & $3.770 * *$ \\
\hline $\mathrm{X} 6 \mathrm{ORG} \rightarrow \mathrm{X} 8$ Performance & -0.213 & $2.040 * *$ & -0.213 & $2.040 * *$ \\
\hline X7 Side Product $\rightarrow$ X8 Performance & 0.0652 & 0.502 & 0.065 & 0.502 \\
\hline \multicolumn{5}{|c|}{ Effect Value of The Path } \\
\hline $\mathrm{X} 1 \rightarrow \mathrm{X} 8$ & \multicolumn{4}{|c|}{0.182} \\
\hline $\mathrm{X} 1 \rightarrow \mathrm{X} 5 \rightarrow \mathrm{X} 8$ & \multicolumn{4}{|c|}{0.128} \\
\hline $\mathrm{X} 1 \rightarrow \mathrm{X} 4 \rightarrow \mathrm{X} 8$ & \multicolumn{4}{|c|}{0.070} \\
\hline $\mathrm{X} 1 \rightarrow \mathrm{X} 6 \rightarrow \mathrm{X} 8$ & \multicolumn{4}{|c|}{-0.172} \\
\hline $\mathrm{X} 2 \rightarrow \mathrm{X} 8$ & \multicolumn{4}{|c|}{-0.236} \\
\hline $\mathrm{X} 2 \rightarrow \mathrm{X} 3 \rightarrow \mathrm{X} 8$ & \multicolumn{4}{|c|}{0.794} \\
\hline
\end{tabular}

Notes: $* *=T$ Stat $>1.96$, Significant on $5 \%$; $*$ T Stat $>1.65$, Significant on $10 \%$.

The total effect value of the path coefficient X1 to X8 is 0.207 . Tangible Asset has a negative insignificant relationship (-0.236) to performance, but the total effect value is significant and positive (0.558).

Judging from the market differentiation strategy construct path coefficient with a value of 0.184 , this is slightly larger than the low-cost strategy on performance which is 0.153 . Meanwhile, the organizational strategy has a negative effect on -0.213 .

The X2 construct (Tangible Asset) has a negative direct relationship (-0.236) and is not significant, but has a significant and positive (0.558) indirect relationship (through the reputation construct). This shows that the $\mathrm{X} 2$ extract influences performance through a moderating variable in the form of the Reputation construct as measured by the ability to provide / own working capital, sufficient cost of buying grain, and a relationship with the bank. This means the 
entrepreneur's ability to obtain/provide costs associated with the main operation of a rice refinery, namely the purchase of raw materials in the form of unhulled rice.

Regarding the relationship between human capital and DP and LC strategies, this study is in accordance with what was written Spanos and Spyros (2001) that company assets, in this case, human capital, affect performance indirectly, but through its ability to implement company strategies. In this study, human capital includes the following aspects: clear performance indicators for employees, the total number of employees, employee experience, and a number of employees with high school education. Thus, the implementation of the company's strategy is highly dependent on the human capital aspects of the company.

From a theoretical perspective, this study solves the problem comprehensively by proving that the RBV model approach can predict the performance of the processing industry. In detail, the uniqueness of this study lies in proving the performance model of the processing industry, where the results reveal that all antecedent variables are divided into three sub-models that can determine the amount of performance achievement. The three sub-models are: 1) tangible asset variables affect performance through reputation variables; 3 ) the Human Capital variable through a low-cost strategy has a significant impact on performance; 4) the human capital variable through marketing differentiation has a significant impact on performance.

These four sub-models serve as a framework for shaping the performance of the processing industry. The proving results of the research model confirm that Reputation acts as a full mediator variable of the Tangible Asset variable, and the low-cost strategy with product differentiation is proven to act as a full mediator variable of the Human Capital variable.

The full mediator creates dependence on antecedent variables to influence processing industry performance. This evidence is in accordance with research Sankaran, Kumar and Das (2020), which revealed that human capital affects the added value of manufacturing in the framework of endogenous growth.

The direct effect from the financial aspect shows that rice refineries are capital intensive businesses, especially in providing capital for the purchase of grain.

Empirically, the RBV model becomes the basis for drafting concepts to improve the performance of the rice milling company. In the findings of this RBV model, it is evident that not all dimensions of the RBV can predict this performance, especially the organizational variables. This illustrates that in fact in the manufacturing industry, organizational function variables do not really affect the amount of performance produced. 


\section{CONCLUSION}

Answering the problem of what are the determinants of industrial performance, through the RBV approach with the SEM PLS model, it can be seen that the tangible asset factor through the mediation of the reputation variable is the most important factor in determining the performance of rice milling companies. This reputation variable is measured by working capital ownership and credit from the bank and the purchase value of the grain. If seen from this, the rice milling business model is a capital intensive business and requires the availability of adequate cash flow. This cash flow management is the determining factor for the success of the company in achieving its best performance.

Company capital in the form of human capital has a real direct relationship to performance. The total effect is greater because it is coupled with a real indirect relationship through Low Cost and Market Differentiation strategies. Meanwhile, company capital in the form of Tangible Asset has a direct and insignificant relationship to performance.

The total effect value of the tangible asset variable is 0.5578 greater than the total effect value of the human capital variable of 0.2068 , this right shows that the rice processing industry its performance is more dependent on the company's tangible assets, which in the process is largely determined by the entrepreneur's reputation variable in managing finances.

\section{ACKNOWLEDGEMENTS}

The authors thank and highly appreciate the Department Regional and Rural Development Planning, Bogor Agricultural University and the Directorate General of Higher Education, Ministry of Research Technology and Higher Education, Republic of Indonesia.

\section{REFERENCES}

Bahri, T.S., Hakim, D.B., Juanda, B. and Sahara, S., 2020. Determining Rice Production and Distribution in Aceh Proviance. IOP Conf. Ser.: Earth Environ. Sci, 644, 012071.

Barney, J., 1991. Firm Resource and Sustained Competitive Advantage. Journal of Manajement, 17, pp.99-120.

Galbreath, J., 2005. Which resources matter the most to firm success? An exploratory study of resource-based theory. Technovation, [e-journal] 25(9), pp.979-987. DOI: 10.1016/j.technovation.2004.02.008.

Hair, J.F., Ringle, C.M. and Sarstedt, M., 2013. Editorial Partial Least Square Structural Equation Modeling: Rigorous Applications, Better Results and Higher Acceptance. Long Range Planning, [e-journal] 46(1-2), pp.1-12. DOI: 10.1016/j.lrp.2013.08.016. 
Juanda, B., 2009. Metodologi Penelitian Ekonomi dan Bisnis. Bogor: IPB Press.

Kaleka, A., 2002. Resources and Capabilities Driving Competitive Advantage in Export Markets: Guidelines for Industrial Exporters. Industrial Marketing Management, [e-journal] 31(3), pp.273-283. DOI: 10.1016/S00198501(00)00148-6.

Madhani, P.M., 2010. Resource Based View (RBV) of Competitive Advantage: An Overview. Economics of Networks eJournal, pp.3-22.

Naderifar, M., Goli, H. and Ghaljaie, F., 2017. Snowball Sampling: A Purposefull Method of Sampling in Qualitative Research. Strides in Development of Medical Education, [e-journal] 14(3), e67670. DOI: 10.5812/sdme.67670.

Nkuba, J., Ndunguru, A., Madulu, R., Lwezaura, D., Kajiru, G., Babu, A., Chalamila, B. and Ley, G., 2016. Rice Value Chain Analysis in Tanzania: Identification of Constraints, Oppurtunities and Upgrading Strategies. African Crop Science Journal, [e-journal] 24(1), pp.73-87. DOI: 10.4314/acsj.v24i1.8S.

Pavithra, A.S., Singh, K.M., Ahmad, N., Sinha, D.K. and Mishra, R.R., 2018. Economic analysis of rice value chain in Bihar and Karnataka States of India. International Journal of Current Microbiology and Applied Sciences, [e-journal] 7(3), pp.2738-2747. DOI: 10.20546/ijcmas.2018.703.316.

Penrose, E., 1959. The Theory of the Growth of the Firm (With a New Introduction by Christos N. Pitelis, 2009. Oxford: Oxford University Press.

Peteraf, M.A., 1993. The Cornerstones of Competitive Advantage: A ResourceBased View. Strategic Management Journal, 14(3), pp.179-191.

Ramon-Jeronimo, J.M., Florez-Lopez, R. and Araujo-Pinzon, P., 2019. Resource-Based View and SMEs Performance Exporting through Foreign Intermediaries: The Mediating Effect of Management Controls. Sustainability, [e-journal] 11(12), 3241. DOI: https://doi.org/10.3390/su11123241.

Ritthaisong, Y., Johri, L.M. and Speece, M., 2014. Sources of Sustainable Competitive Advantage: The Case of Ricemilling Firms in Thailand. British Food Journal, [e-journal] 116(2), pp.272-291. DOI: 10.1108/BFJ-01-2012-0003.

Rothaermel, F.T. and Deeds, D.L., 2001. More Good Things Are Not Necessarily Better: An Empirical Study Of Strategic Alliances, Experience Effects, And Innovative Output In High-Technology Start-Ups. Acedemy of Management, [ejournal] 2001(1), pp. 85-103. DOI: 10.5465/apbpp.2001.6133869.

Rothaermel, F.T., 2015. Strategic Management. Second Edition. New York: McGraw-Hill Education.

Sankaran, A.K., Kumar, S. and Das, M., 2020. An endogenous growth approach on the role of energy, human capital, finance and technology in explaining manufacturing value-added: A multi-country analysis. Heliyon, [e-journal] 6(7), e04308. DOI: 10.1016/j.heliyon.2020.e04308. 
Spanos, Y.E. and Spyros, L., 2001. An Examination Into The Causal Logic of Rent Generation: Contrasting Porter's Competitive Strategy Framework and The Resource-Based Perspective. Strategic Management Journal, [e-journal] 22(10), pp.907-934. DOI: 10.1002/smj.174.

Suoth, O., 2017. Desain Jaringan Supply Chain Komoditas Beras Di Desa Karondoran Kecamatan Langowan Timur Kabupaten Minahasa. Jurnal Emba, [e-journal] 5(2), pp.511-519. DOI: 10.35794/emba.5.2.2017.15716.

Teece, D.J., Pisano, G. and Shuen, A., 1997. Dynamic Capabilities and Strategic Management. Strategic Management Journal, [e-journal] 18(7), pp.509-533. DOI: 10.1002/(SICI)1097-0266(199708)18:7<509::AID-SMJ882>3.0.CO;2-Z.

\section{ABOUT AUTHORS}

T. Saiful Bahri ${ }^{0000-0003-0707-6051}$ (T.S.B.) - Doctor, Department of Agribusiness, Faculty of Agriculture, Universitas Syiah Kuala (USK), Banda Aceh, Indonesia, e-mail: tsaifulbahri@unsyiah.ac.id.

Dedi Budiman Hakim ${ }^{0000-0002-8137-5159}$ (D.B.H.) - Doctor, Department of Economics, Faculty of Economics and Management (FEM) of Bogor Agricultural University, International Centre for Applied and International Centre for Applied Finance and Economic IPB, Bogor, Indonesia, e-mail: dedihakim@gmail.com.

Bambang Juanda 0000-0002-3333-5531 (B.J.) - Prof., Department of Economic, Faculty of Economics and Management (FEM) of Bogor Agricultural University, Bogor, Indonesia, e-mail: bbjuanda@yahoo.com.

Sahara Sahara ${ }^{0000-0003-0905-6388}$ (S.S.) - Doctor, Department of Economic, Faculty of Economics and Management (FEM) of Bogor Agricultural University, Bogor, Indonesia, e-mail: sahara_ipb@yahoo.com.

\section{AUTHOR CONTRIBUTIONS}

Conceptualization, T.S.B. and D.B.H.; Methodology, T.S.B., B.J., and S.S.; Software, T.S.B. and B.J.; Validation, T.S.B. and S.S.; Formal analysis, T.S.B.; Investigation, T.S.B.; Resources, T.S.B. and D.B.H.; Data curation, T.S.B. and B.J.; Original draft preparation, T.S.B.; Review and editing, T.S.B., D.B.H. and B.J.; Supervision, D.B.H., B.J. and S.S. 


\section{CONFLICTS OF INTEREST}

The authors declare no conflict of interest. The funders had no role in the design of the study; in the collection, analyses, or interpretation of data; in the writing of the manuscript, or in the decision to publish the results.

(C) 2021 by the authors. Submitted for possible open access publication under the terms and conditions of the Creative Commons Attribution (CC-BY) license (http://creativecommons.org/licenses/by/4.0/). 